\title{
Standardization of surgical procedures for identifying best practices and training.
}

\author{
Armstrong, T. ${ }^{\mathrm{a}}$, D. Yu ${ }^{\mathrm{a}}$, A. Frischknecht ${ }^{\mathrm{b}}$, R. Minter ${ }^{\mathrm{b}}$, P. Andreatta ${ }^{\mathrm{c}}, \mathrm{S} . \mathrm{Kasten}^{\mathrm{b}}$ \\ ${ }^{a}$ Center for Ergonomics, University of Michigan, 1205 Beal Ave., Ann Arbor, MI, USA, ${ }^{b}$ Department of Surgery, \\ University of Michigan, Ann Arbor, MI, 48109, USA, ${ }^{\circ}$ Department of Medical Education, University of Michigan, \\ Ann Arbor, MI, 48109, USA
}

\begin{abstract}
A taxonomy was developed a) to describe surgical procedures with sufficient detail to review differences among surgeons, b) to examine the relationship between individual technique and outcomes, c) to enable surgeons to standardize technique around best practices and d) to identify clinical-evidence-based key points of teaching and assessment for surgical training. Sixty-seven microvascular anastomoses were recorded through video cameras mounted in the dissecting microscope. A hierarchical task analysis was used to decompose the observed procedures into successive levels of detail. The results were then presented to individual and small groups of microvascular surgeons to help define steps and step attributes necessary to describe a procedure so that other surgeons can perform the procedure exactly the same way. Coincidently, it was found that because the surgeons' attention is confined to a very small field of view in which they can see only the veins and arteries and the ends of their instruments, they often have difficulty communicating with others in the operating room. Analyses of selected cases using the proposed taxonomy shows how subtle details are revealed that may affect outcomes, and indicate specific training needs. By comparing different methods and outcomes, it should be possible to identify best practices for given conditions.
\end{abstract}

Keywords: Surgery, methods, taxonomy, standardization, task analysis, training

\section{Introduction}

This work aims to develop a taxonomy a) to describe surgical procedures with sufficient detail to review differences among surgeons, b) to examine the relationship between individual technique and outcomes, c) to enable surgeons to standardize technique around best practices and d) to identify clinical-evidence-based key points of teaching and assessment for surgical training.

Standardization of work is the cornerstone of modern production methods. In modern times it has it roots in the work of Taylor and Gilbreth. Standardized work helps to eliminate errors due to omission or admission. It provides benchmarks by which workers can determine when corrective actions are required. Standardized work facilitates training and retraining of workers by providing defined steps that can be practiced and evaluated. Underlying standardized work is a language that uniquely describes each step so that it can be understood and communicated between workers and supervisors. The fields of medicine and surgery have begun to embrace standardization and have made significant strides in some areas, such as timing of antibiotic administration before surgery. However, in spite of recognition of the quality and safety advantages of standardized work, it has not achieved a wide level of acceptance in terms of actual surgical technique, even in the face of obvious variation between surgeons performing the "same" procedure.

Medical and surgical procedures often involve long sequences of steps that vary from cases to case. In some cases these variations are justified based on anatomical, physiological or pathological variations in the patient. In other cases variations may be due to the kind of equipment used and the clinicians' preferences, which are often formed during training through observation of respected mentors, and often considered sacrosanct. Variations may also result from a lack of skill or inexperience of the clinicians. Whatever the reason for the variation, it is uncertain 
presently which exact methods represent the best practice.

A significant barrier in studying best technique in surgery is lack of a method or instrument for describing and rating technique with sufficient detail and reliability. A number of assessment tools have been developed (generally for use in training programs) for measuring overall performance in generalized domains such as "tissue handling," "knowledge of instruments," "proper use of assistants," etc., and even performance of specific tasks, such as knot tying. $[2,3,5,6,9,10]$. Yet there remains a need for a language or taxonomy that can be used to describe complex surgical procedures with sufficient detail to detect differences amongst experts performing the same procedure. Such a taxonomy can be used to 1) study the relation between surgical technique and outcomes to determine best methods; 2) describe those methods to other surgeons in practice so that they can be performed in exactly the same way under the same conditions; 3) establish key points for teaching and assessment in surgical training; 4) provide the basis for highly objective assessment instruments.

\section{Methods}

A taxonomy was developed using traditional hierarchical task analysis, HTA, methods described by $[4,7,8,11]$. The particular study focused on microvascular surgical anastomoses, but many of the tools and findings can be generalized to other types of surgical and clinical procedures

Development of the taxonomy was an iterative process in which HTAs were applied to observed cases. The cases were then reviewed with surgeons individually and in groups. Feedback from the surgeons was used to revise and improve the taxonomy. The proposed work was approved the University of Michigan Institutional Review Board, IRB.

The study focused on microvascular surgical anastomosis, a procedure performed to join (reconnect) veins and arteries of tissues that are relocated from one part of the body to another. Such procedures are commonly performed in reconstructive surgery following traumatic injuries, following surgery to remove cancerous tissues, or to repair congenital defects. Microvascular anastomoses are performed under stereoscopic dissecting microscopes with 620x magnification by two surgeons. The veins and arteries are typically $2-3 \mathrm{~mm}$ in diameter, but can be as small a $0.5 \mathrm{~mm}$. One surgeon directs the procedure and performs the critical cuts, placements and sutures while the second surgeon assists by holding tools and tissues, cleaning the surgical field, etc. In a teaching setting a trainee (surgical resident or fellow) may be allowed to perform some or all of the critical procedures. The microscopes have two sets of eyepieces so that both surgeons can view the field at the same time. The microscopes are equipped with video cameras, which facilitate recording the procedures. In addition, a second video camera recorded the upper bodies of the surgeons.

This particular procedure was selected for analysis due to the complex nature of the operation and the ability to assess specific outcomes related to the procedure. Failure of these procedures results in a significant morbidity for the patient, and thus optimization of technique may result in significant savings for the patient with respect to health outcomes. .

\subsection{Documentation of cases}

The study procedures, benefits and risks were explained to the participating surgeons and patients before they gave written consent to participate in the study. The study was purely observational; the surgeons were not asked to alter their typical technique. A total of 67 cases have been documented. From those 67 cases, 8 cases that encompass a wide range of conditions and methods were selected for detailed analysis and development of the basic taxonomy.

\subsection{Video analysis}

A video analysis tool was developed to play and annotate video recordings as described by Armstrong et al. [1]. Annotations were linked to the video so that the videostream for a given annotation could be easily queued. The software also makes it possible to add, change or delete annotations. As the taxonomy evolved, pull-down menus were added to facilitate identifying and recording the desired taxonomy features.

\subsection{The taxonomy}

The proposed taxonomy includes three basic levels: 1) Tasks, 2) Subtasks and 3) There is a provision for a fourth level, Movements, but that level has not yet been implemented. Each level includes a group of members. For example, Level 1 - Tasks, includes actions such as "prepare host site," "harvest donor tissue," and "microvascular anastomosis." 
Each task includes a set of subtasks. For example "microvascular anastomosis" includes: "prepare vessels," "join vessels," "inspect anastomosis," "modify/repair anastomosis," "maintain field and vessels." Each subtask is defined by its objective and has discrete start and stop times. Similarly, subtasks are decomposed into elements. Elements are also defined by objectives and have discrete start and stop times.

Each task, subtask and element has a set of attributes that help to uniquely define an instance of that task, subtask and element. Attributes include: method, work object, tool, material, environmental and anatomical/physiological conditions, ergonomics and outcomes. The attributes of an element apply to all of the corresponding subtasks and tasks, but the attributes of a subtask do not necessarily apply to all corresponding elements. Similarly the attributes of a subtask apply to all corresponding tasks, but the attributes of a given task do necessarily not apply to all corresponding subtasks or elements.

A surgical procedure is characterized by both the sequence of tasks, subtasks and elements and the corresponding attributes. The attributes of a subtask often determine both the sequence of elements and their attributes. In some cases the procedure may be dictated by the selection of a particular tool. For example, an end-to-end anastomosis may be performed using sutures or a Mechanical coupler. If sutures are used, then a series of stabilize vessel, drive needle, tie suture and cut suture elements will be repeated 6 to 10 times. If a coupler is used then the single sequence of feed vessel through coupler, place edges of vessel over pegs and close coupler elements will be performed.

In some instances subtasks and elements must be performed serially, but in other instances, they may be performed in parallel. For example, it is necessary to "prepare vessel" before "joining vessel," but in some cases, the need to perform additional "prepare vessel" elements will become apparent after the "join vessel" subtask has begun. The objective of the "maintain field and vessel" subtask is keep the surgical field clear of blood so that the surgeon can see what he is doing and dried blood does not interfere with use of the tools or manipulation of the tissue. The elements of "maintain field" are performed as needed while the other subtasks are performed.

In some cases the sequence of elements may be a matter of skill and preference by the clinician. For example, some surgeons may choose to remove all connective tissue around a vein or artery, while others may choose to remove only a minimum amount.
These differences would be captured by the number of "strip adventitia" element events and by the attributes of the artery or vein. Similarly, some surgeons may have difficulty driving the needle through the thin wall of a vein or the thick wall of an artery. The first and last sutures are often most challenging. The number of "drive needle" element events and their corresponding outcome attributes would capture this difference.

Eight surgical cases were used for HTA and development of the present taxonomy. The development has been an iterative process. The video analysis software was used to parse the jobs into conspicuous subtasks and elements and to record relevant information about tools and conditions. The results were then shown to individual and small groups of microvascular surgeons who identified critical details, verified correct names of tissues and tools and provided feedback regarding the proposed subtask specific "immediate outcomes." These immediate outcomes were defined as measurable results related to the specific subtask. The geometry of an incision and the spacing of sutures are examples of immediate outcomes. Immediate outcomes are distinguished from intermediate and long-term outcomes. Arterial and venous flow and leaks are examples of intermediate outcomes. Survival of the transplanted tissue is an example of a long-term outcome.

\section{Results}

Table I shows sample results for the first stitch of two "join vessel" subtasks for two different patients and two different surgeons. It can be seen that the first case required two attempts to Support and Drive Needle, which is to pass the suture through the wall of the vessel, while the second case required four attempts.

Tables IIa and b show some of the key attributes that correspond to each element of the taxonomy. From the work object attribute it can be seen that in Case 1 the surgeon begins with the donor artery and in Case 2 the surgeon begins with the host artery. In both cases the needle is inserted into the vessel from the outside in for the first artery and then the inside out for the second artery. The surgeon then pulls on the ends of the suture and ties a knot to hold the two ends of the artery together. Additional sutures are then placed around the anastomosis. The suture pattern and the first, intermediate and last sutures are important element attributes because they are performed differently and require different skill levels. 
Table I

Taxonomy elements for portions of two surgical cases

\begin{tabular}{|l|l|}
\hline Case 1 Surgeon 1 & Case 2 Surgeon 3 \\
\hline 1. Align vessels & 1. Align vessels \\
2. Support and Drive needle & 2. Support and Drive needle \\
3. Support and Drive needle & 3. Support and Drive needle \\
4. Align vessels & 4. Support and Drive needle \\
5. Align vessels & 5. Support and Drive needle \\
6. Support and Drive needle & 6. Align vessels \\
7. Tie suture & 7. Support and Drive needle \\
8. Cut suture & 8. Tie suture \\
& 9. Cut suture \\
\hline
\end{tabular}

The immediate outcomes are successful unless noted otherwise. It can be seen that the most common problem with suturing is failure to fully pierce and pass the needle through the artery. Other important attributes include tools and ergonomics. Surgeons use a vast array of tools, but often their choice is limited by what is immediately available. For example, for economy of motion, rather than switching instruments to a forceps to reposition tissue, a surgeon may use the tip of a needle, which is already in hand.

Ergonomic attributes refer to factors that affect the ability of the surgeon to gather necessary information, process it and physically perform the steps of a procedure. In several instances it could be seen that the work object moved outside of the field of view, which required repositioning the work or the microscope.

Grasp position refers to where the needle is held form the point, which affects the ability of the surgeons to position the needle. Needle grasp position for Case 2 is greater than $2 / 3$ the needle length vs Case 1 with grasp position from $1 / 2-2 / 3$ the needle length.

Ergonomics attributes also include exertion duration and frequency, force and posture that may cause the surgeon to fatigue or develop musculoskeletal pain. Both surgeons must maintain static trunk and neck postures to observe their work through the microscope.

\section{Discussion}

Several important features are apparent from the HTA and descriptions using the proposed taxonomy. The first observation is that both jobs involve several common features, e.g., alignment of the vessels, supporting and driving the needle and attached suture, tying knots and trimming sutures. Knot tying is often used to evaluate surgical performance $[2,3,9]$. In both examples, the outcome of knot tying was successful.

The most common problem found in these cases was failure to drive the needle that resulted in only poking the artery. The walls of the arteries are thick and require a well-directed forceful exertion to pierce the arterial wall. Sufficient force also must be exerted against the needle drive to prevent the needle from slipping. Also, the artery must be stabilized so that it is not deflected out of the way of the needle.

Failure to complete a stitch also may be related to how the needle is held. Needle grasp position for Case 2 is greater than $2 / 3$ the needle length vs Case 1 with grasp position from $1 / 2-2 / 3$ the needle length. Case 2 requires more attempts/pokes and motions than Case 1.

Failure to exert sufficient force to adequately stabilize the artery or to correctly position the needle may result in a poorly placed stitch or a poke, both of which may increase the risk of a poor outcome by causing tissue trauma. A poke or a poorly placed stitch may require additional time to achieve the ultimate placement of the stitch, which further reduces the risk of a favorable long-term outcome - survival of the donor tissue due to prolonged ischemia. Practice tasks might be designed to help train or retrain surgeons to support and drive the needle if this is identified as a key attribute which affects the outcome. Such a task might involve the use of a small silicon tube lubricated with water or oil.

The most conspicuous ergonomic problems involved the work object moving out of the field of view, prolonged static postures, and repetitive motions. The reason for the work object moving out of the field of view needs to be explored further to determine if it is related to skill or to the type of procedure and position of the flap.

Prolonged static postures are associated with musculoskeletal pain. Microvascular surgeons work in pairs. In these cases, some prefer to stand and some prefer to sit, making it difficult to position the microscope optimally for both surgeons. Microsurgery is also very hand intensive. Repetitive motions of the hand and wrist are associated with chronic muscle, tendon and nerve injures of the upper limb. Anecdotally, many of the surgeons volunteered that they frequently experience musculoskeletal pain that interferes with their work. Further studies are needed to evaluate the prevalence of musculoskeletal pain in microvascular and other surgeons. 
Table IIa

Attributes of taxonomy elements for Case 1

\begin{tabular}{|c|c|c|c|c|c|c|c|}
\hline \multirow{2}{*}{ Element } & \multicolumn{7}{|c|}{ Attributes of element } \\
\hline & $\begin{array}{c}\text { Work } \\
\text { Object }\end{array}$ & Methods & Tools & Matl. & Conditions & Ergonomics & $\begin{array}{c}\text { Immediate } \\
\text { Outcome }\end{array}$ \\
\hline $\begin{array}{l}\text { 1. Align } \\
\text { vessels }\end{array}$ & $\begin{array}{l}\text { Donor } \\
\text { Artery }\end{array}$ & $\begin{array}{l}\text { Align Method: Hold adventitia on } \\
\text { outside of vessel }\end{array}$ & Forceps: Jewelers & & $\begin{array}{l}\text { Stitch Num- } \\
\text { ber: } 1 \text { st stitch }\end{array}$ & Motions: 8 & \\
\hline $\begin{array}{l}\text { 2. Sup- } \\
\text { port and } \\
\text { Drive } \\
\text { needle }\end{array}$ & $\begin{array}{l}\text { Donor } \\
\text { Artery }\end{array}$ & $\begin{array}{l}\text { Support Method: Hold adventitia } \\
\text { on outside of vessel; Number of } \\
\text { Bites: Two; Grasp Position: } 1 / 2- \\
\text { 2/3; 1st Placement: Back wall }\end{array}$ & $\begin{array}{l}\text { Forceps: Jewelers; } \\
\text { Needle driver; } \\
\text { Needle; Needle } \\
\text { Size: } 9 / 0\end{array}$ & Suture & $\begin{array}{l}\text { Stitch Num- } \\
\text { ber: 1st } \\
\text { stitch; Direc- } \\
\text { tion: Out- } \\
\text { side-In }\end{array}$ & $\begin{array}{l}\text { Needle } \\
\text { Grasp Posi- } \\
\text { tion: } 1 / 2-2 / 3 \\
\text {; Motions: } 2 \text {; }\end{array}$ & $\begin{array}{l}\text { Failed } \\
\text { Attempt: } \\
\text { Poke }\end{array}$ \\
\hline $\begin{array}{l}\text { 3. Sup- } \\
\text { port and } \\
\text { Drive } \\
\text { needle }\end{array}$ & $\begin{array}{l}\text { Donor } \\
\text { Artery }\end{array}$ & $\begin{array}{l}\text { Support Method: Hold adventitia } \\
\text { on outside of vessel; Support } \\
\text { Method: Hold by inserting forceps } \\
\text { in lumen; Support Method: Push } \\
\text { vessel with instrument }\end{array}$ & $\begin{array}{l}\text { Forceps: Jewelers; } \\
\text { Needle; Needle } \\
\text { Size: } 9 / 0 \text {; Needle } \\
\text { driver }\end{array}$ & Suture & $\begin{array}{l}\text { Stitch Num- } \\
\text { ber: 1st } \\
\text { stitch; Direc- } \\
\text { tion: Out- } \\
\text { side-In }\end{array}$ & $\begin{array}{l}\text { Motions: } 23 \\
\text { Vision: } \\
\text { Moved out } \\
\text { of Field of } \\
\text { View }\end{array}$ & \\
\hline $\begin{array}{l}\text { 4. Align } \\
\text { vessels }\end{array}$ & $\begin{array}{l}\text { Donor } \\
\text { Artery }\end{array}$ & $\begin{array}{l}\text { Align Method: Hold adventitia on } \\
\text { outside of vessel }\end{array}$ & Forceps: Jewelers & & $\begin{array}{l}\text { Stitch Num- } \\
\text { ber: 1st stitch }\end{array}$ & Motions: 3 & \\
\hline $\begin{array}{l}5 . \text { Align } \\
\text { vessels }\end{array}$ & $\begin{array}{l}\text { Host } \\
\text { Artery }\end{array}$ & $\begin{array}{l}\text { Align Method: Hold adventitia on } \\
\text { outside of vessel }\end{array}$ & Forceps: Jewelers & & $\begin{array}{l}\text { Stitch Num- } \\
\text { ber: 1st stitch }\end{array}$ & Motions: 3 & \\
\hline $\begin{array}{l}\text { 6. Sup- } \\
\text { port and } \\
\text { Drive } \\
\text { needle }\end{array}$ & $\begin{array}{l}\text { Host } \\
\text { Artery }\end{array}$ & $\begin{array}{l}\text { Support Method: Hold adventitia } \\
\text { on outside of vessel; Number of } \\
\text { Bites: Two; Grasp Position: } 1 / 2- \\
\text { 2/3; 1 st Placement: Back wall } \\
\text { (Farthest point); Number of Pushes: } \\
1\end{array}$ & $\begin{array}{l}\text { Forceps: Jewelers; } \\
\text { Needle driver; } \\
\text { Needle Size: } 9 / 0 \text {; } \\
\text { Needle }\end{array}$ & Suture & $\begin{array}{l}\text { Stitch Num- } \\
\text { ber: 1st } \\
\text { stitch; Direc- } \\
\text { tion: Inside- } \\
\text { Out }\end{array}$ & $\begin{array}{l}\text { Needle } \\
\text { Grasp Posi- } \\
\text { tion: } 1 / 2-2 / 3 \text {; } \\
\text { Motions: } 34 ; \\
\text { Vision: } \\
\text { Moved Out } \\
\text { of Field of } \\
\text { View }\end{array}$ & \\
\hline $\begin{array}{l}\text { 7. Tie } \\
\text { suture }\end{array}$ & $\begin{array}{l}\text { Host } \\
\text { Artery; } \\
\text { Donor } \\
\text { Artery; } \\
\text { Suture }\end{array}$ & Tie: 3 throws & $\begin{array}{l}\text { Forceps: Jewelers; } \\
\text { Needle driver }\end{array}$ & Suture & $\begin{array}{l}\text { Stitch Num- } \\
\text { ber: 1st stitch }\end{array}$ & & \\
\hline $\begin{array}{l}\text { 8. Cut } \\
\text { suture }\end{array}$ & Suture & & $\begin{array}{l}\text { Forceps: Jewelers; } \\
\text { Needle driver; } \\
\text { Scissors: Straight }\end{array}$ & Suture & $\begin{array}{l}\text { Stitch Num- } \\
\text { ber: 1st stitch }\end{array}$ & & \\
\hline
\end{tabular}


Table IIb

Attributes of taxonomy elements for Case 2

\begin{tabular}{|c|c|c|c|c|c|c|c|}
\hline \multirow{2}{*}{ Element } & \multicolumn{7}{|c|}{ Attributes of element } \\
\hline & $\begin{array}{c}\text { Work } \\
\text { Object }\end{array}$ & Methods & Tools & Matl. & Conditions & Ergonomics & $\begin{array}{c}\text { Immediate } \\
\text { Outcome }\end{array}$ \\
\hline $\begin{array}{l}\text { 1. Align } \\
\text { vessels }\end{array}$ & $\begin{array}{l}\text { Host } \\
\text { Artery; } \\
\text { Donor } \\
\text { Artery }\end{array}$ & $\begin{array}{l}\text { Align Method: Hold adventitia on } \\
\text { outside of vessel }\end{array}$ & Forceps: Jewelers & & $\begin{array}{l}\text { Stitch Num- } \\
\text { ber: } 1 \text { st stitch }\end{array}$ & Motions: 3 & \\
\hline $\begin{array}{l}\text { 2. Sup- } \\
\text { port and } \\
\text { Drive } \\
\text { needle }\end{array}$ & $\begin{array}{l}\text { Host } \\
\text { Artery }\end{array}$ & $\begin{array}{l}\text { Support Method: Hold adventitia } \\
\text { on outside of vessel; Grasp Posi- } \\
\text { tion: >2/3; 1 st Placement: Back } \\
\text { wall (Farthest point) }\end{array}$ & $\begin{array}{l}\text { Forceps: Jewelers; } \\
\text { Needle: Unidenti- } \\
\text { fied; Needle Size: } \\
\text { 9/0; Needle driver }\end{array}$ & Suture & $\begin{array}{l}\text { Stitch Num- } \\
\text { ber: } 1 \text { st } \\
\text { stitch; Direc- } \\
\text { tion: Out- } \\
\text { side-In }\end{array}$ & $\begin{array}{l}\text { Motions: } 1 \\
\text { Needle } \\
\text { Grasp Posi- } \\
\text { tion: }>2 / 3\end{array}$ & $\begin{array}{l}\text { Failed } \\
\text { Attempt: } \\
\text { Poke }\end{array}$ \\
\hline $\begin{array}{l}\text { Sup- } \\
\text { port and } \\
\text { Drive } \\
\text { needle }\end{array}$ & $\begin{array}{l}\text { Host } \\
\text { Artery }\end{array}$ & $\begin{array}{l}\text { Support Method: Hold adventitia } \\
\text { on outside of vessel; Grasp Posi- } \\
\text { tion: >3/4; 1st Placement: Back } \\
\text { wall (Farthest point) }\end{array}$ & $\begin{array}{l}\text { Forceps: Jewelers; } \\
\text { Needle: Unidenti- } \\
\text { fied; Needle Size: } \\
\text { 9/0; Needle driver }\end{array}$ & Suture & $\begin{array}{l}\text { Stitch Num- } \\
\text { ber: } 1 \text { st } \\
\text { stitch; Direc- } \\
\text { tion: Out- } \\
\text { side-In }\end{array}$ & $\begin{array}{l}\text { Motions: } 1 \\
\text { Needle } \\
\text { Grasp Posi- } \\
\text { tion: }>2 / 3\end{array}$ & $\begin{array}{l}\text { Failed } \\
\text { Attempt: } \\
\text { Poke }\end{array}$ \\
\hline $\begin{array}{l}\text { 4. Sup- } \\
\text { port and } \\
\text { Drive } \\
\text { needle }\end{array}$ & $\begin{array}{l}\text { Host } \\
\text { Artery }\end{array}$ & $\begin{array}{l}\text { Support Method: Hold adventitia } \\
\text { on outside of vessel; Grasp Posi- } \\
\text { tion: >3/4; 1st Placement: Back } \\
\text { wall (Farthest point) }\end{array}$ & $\begin{array}{l}\text { Forceps: Jewelers; } \\
\text { Needle: Unidenti- } \\
\text { fied; Needle Size: } \\
\text { 9/0; Needle driver }\end{array}$ & Suture & $\begin{array}{l}\text { Stitch Num- } \\
\text { ber: } 1 \text { st } \\
\text { stitch; Direc- } \\
\text { tion: Out- } \\
\text { side-In }\end{array}$ & $\begin{array}{l}\text { Motions: } 4 \\
\text { Needle } \\
\text { Grasp Posi- } \\
\text { tion: }>2 / 3\end{array}$ & $\begin{array}{l}\text { Failed } \\
\text { Attempt: } \\
\text { Poke }\end{array}$ \\
\hline $\begin{array}{l}\text { 5. Sup- } \\
\text { port and } \\
\text { Drive } \\
\text { needle }\end{array}$ & $\begin{array}{l}\text { Host } \\
\text { Artery }\end{array}$ & $\begin{array}{l}\text { Support Method: Hold adventitia } \\
\text { on outside of vessel; Support } \\
\text { Method: Hold by inserting forceps } \\
\text { in lumen; Grasp Position: > 3/4; 1st } \\
\text { Placement: Back wall (Farthest } \\
\text { point); Number of Pushes: } 1 \\
\end{array}$ & $\begin{array}{l}\text { Forceps: Jewelers; } \\
\text { Needle: Unidenti- } \\
\text { fied; Needle Size: } \\
\text { 9/0; Needle driver }\end{array}$ & Suture & $\begin{array}{l}\text { Stitch Num- } \\
\text { ber: } 1 \text { st } \\
\text { stitch; Direc- } \\
\text { tion: Out- } \\
\text { side-In }\end{array}$ & $\begin{array}{l}\text { Motions: } 1 \\
\text { Needle } \\
\text { Grasp Posi- } \\
\text { tion: }>2 / 3\end{array}$ & \\
\hline $\begin{array}{l}\text { 6. Align } \\
\text { vessels }\end{array}$ & $\begin{array}{l}\text { Donor } \\
\text { Artery }\end{array}$ & $\begin{array}{l}\text { Align Method: Hold adventitia on } \\
\text { outside of vessel }\end{array}$ & Forceps: Jewelers & & $\begin{array}{l}\text { Stitch Num- } \\
\text { ber: } 1 \text { st stitch }\end{array}$ & $\begin{array}{l}\text { Assistant } \\
\text { Motions: } 6 \\
\end{array}$ & \\
\hline $\begin{array}{l}\text { 7. Sup- } \\
\text { port and } \\
\text { Drive } \\
\text { needle }\end{array}$ & $\begin{array}{l}\text { Donor } \\
\text { Artery }\end{array}$ & $\begin{array}{l}\text { Support Method: Hold adventitia } \\
\text { on outside of vessel; Number of } \\
\text { Bites: Two; Number of Pushes: } 1 \text {; } \\
\text { Grasp Position: >3/4; 1st Place- } \\
\text { ment: Back wall (Farthest point) }\end{array}$ & $\begin{array}{l}\text { Forceps: Jewelers; } \\
\text { Needle: Unidenti- } \\
\text { fied; Needle Size: } \\
\text { 9/0; Needle driver }\end{array}$ & Suture & $\begin{array}{l}\text { Stitch Num- } \\
\text { ber: } 1 \text { st } \\
\text { stitch; Direc- } \\
\text { tion: Inside- } \\
\text { Out }\end{array}$ & $\begin{array}{l}\text { Motions: } 33 \text {; } \\
\text { Vision: } \\
\text { Moved out } \\
\text { of field of } \\
\text { view; } \\
\text { Needle } \\
\text { Grasp Posi- } \\
\text { tion: }>2 / 3\end{array}$ & \\
\hline $\begin{array}{l}\text { 8. Tie } \\
\text { suture }\end{array}$ & $\begin{array}{l}\text { Host } \\
\text { Artery; } \\
\text { Donor } \\
\text { Artery }\end{array}$ & Tie: 3 throws & $\begin{array}{l}\text { Forceps: Jewelers; } \\
\text { Needle driver }\end{array}$ & Suture & $\begin{array}{l}\text { Stitch Num- } \\
\text { ber: } 1 \text { st stitch }\end{array}$ & $\begin{array}{l}\text { Motions: } 28 ; \\
\text { Vision: } \\
\text { Moved out } \\
\text { of field of } \\
\text { view }\end{array}$ & \\
\hline $\begin{array}{l}\text { 9. Cut } \\
\text { suture }\end{array}$ & Suture & & $\begin{array}{l}\text { Needle driver; } \\
\text { Scissors: Straight; } \\
\text { Forceps: Jewelers }\end{array}$ & & $\begin{array}{l}\text { Stitch Num- } \\
\text { ber: } 1 \text { st stitch }\end{array}$ & Motions: 2 & \\
\hline
\end{tabular}

Surgical procedures are long and complex. Hierarchical task analysis makes it possible to describe surgical procedures and to adjust the level of granularity as needed to capture details that may affect outcomes. The results show that it is not only important to describe what the surgeons do, but also how they do it, the tools and conditions that affect how they do it and the associated procedural and task outcomes. Traditional evaluation criteria have focused on overall outcome, which may overlook fac- tors that contributed to a failure. Traditional tools for evaluation of surgeons focus on selected skills, such as knot tying. HTA and the proposed taxonomy can be used to examine the details of a specific operation, such as aligning the vessels, supporting the tissues and driving the needle in microvascular anastomosis, that affect the outcome of a given stitch placement and the overall procedure. Multiple failed attempts to drive a needle such as shown in Table II, may indicate the need for training in how to support the vessel 
or grasp and position the needle. This information can be used to focus training for new and experienced surgeons.

HTA and the proposed taxonomy can also be used to compare different equipment. Determination of the best method is beyond the scope of this paper, the cases can still be used to hypothesize alternative methods that might be better than these. For example, it can be seen that considerable skill and time are required to complete 8 to 10 sutures per vessel. During this time the donor tissue is ischemic and dying. In some cases a coupler can be used to join two vessels end to end with less trauma and less time than by suturing. Future studies should examine the relationship between outcome and coupling techniques.

The proposed taxonomy shows great promise for describing and evaluating surgical procedures. The taxonomy can be applied to video recordings of routine procedures. Increasingly operating rooms are being equipment with video recording equipment. The hierarchical properties of the taxonomy enables the user to focus on those parts of the case that are of interest to investigate factors affecting outcomes or to identify training or retraining needs. The taxonomy facilitates communication among surgeons and among teachers and students. By recording cases and applying the proposed taxonomy it should be possible to identify and control factors that lead to adverse immediate, intermediate and long term outcomes and to determine overall best practices for a given set of conditions so that they can be taught to all surgeons.

\section{Conclusions}

HTA and the proposed taxonomy are promising tools for:

- Describing microvascular procedures with sufficient detail to distinguish between different cases and surgeons.

- Identifying how specific steps and factors affect immediate outcomes, which in turn may affect overall out comes.

- Standardizing surgical technique around best practices

- Identifying specific elements that the might be improved with training or retraining, and subsequently,

- Development of new assessment instruments that focus specifically on those steps or attributes of technique where variation has been demonstrated to have the greatest impact on patient outcomes
Continued observations and analyses of cases will help to strengthen and operationalize these conclusions.

\section{Acknowledgements}

The project was funded in part by the project "Linking Surgical Education and Patient Outcomes Using Video Analysis and Hierarchical Decomposition of Surgical Techniques" from the Graduate Medical Education Innovations Program through the University of Michigan Health Systems, and by the project "Assessment of the Biomechanical Impact in Microvascular Surgeries on Surgeon Health and Performance" from the National Institute for Occupational Safety and Health.

\section{References}

[1]Armstrong, T., et al. Time Based Job Analysis of Control of Work-Related Musculoskeletal Disorders. "Ergonomics in the Digital Age," $X V^{\text {th }}$ Triennial Congress of the International Ergonomics Association and The $7^{\text {th }}$ Joint Conference of Ergonomics Society of Korea/Japan Ergonomics Society, August 24-29, Seoul, Korea (2003).

[2] W. Chan, N. Niranjan, and V. Ramakrishnan. "Structured assessment of microsurgery skills in the clinical setting." $J$ Plast Reconstr Aesthet Surg 63.8 (2010): 1329-34.

[3] P. U. Kalu, et al. "How do we assess microsurgical skill?" Microsurgery 25.1 (2005): 25-9.

[4] L. MacKenzie, J. A. Ibbotson, C. G. L. Cao, A. J. Lomax, C. "Hierarchical decomposition of laparoscopic surgery: a human factors approach to investigating the operating room environment." Minimally Invasive Therapy \& Allied Technologies 10.3 (2001): 121-27.

[5] J. Price, et al. "A randomized evaluation of simulation training on performance of vascular anastomosis on a high-fidelity in vivo model: The role of deliberate practice." $J$ Thorac Cardiovasc Surg (2011).

[6] R. K. Reznick, and H. MacRae. "Teaching surgical skills-changes in the wind." N Engl J Med 355.25 (2006): 2664-9.

[7] S. K. Sarker, et al. "Constructing hierarchical task analysis in surgery." Surg Endosc 22.1 (2008): 107-11.

[8] N. A. Stanton. "Hierarchical task analysis: Developments, applications, and extensions." Applied Ergonomics 37.1 (2006): 55-79.

[9] C. L. Temple, and D. C. Ross. "A new, validated instrument to evaluate competency in microsurgery: the University of Western Ontario Microsurgical Skills Acquisition/Assessment instrument [outcomes article]." Plast Reconstr Surg 127.1 (2011): 215-22.

[10]M. C. Vassiliou, et al. "A global assessment tool for evaluation of intraoperative laparoscopic skills." Am J Surg 190.1 (2005): 107-13.

[11]D. Yu, S.J. Kasten, T.J. Armstrong. "Development of a hierarchical taxonomy for standardization of microvascular surgery." Human Factors and Ergonomics Society Annual Meeting Proceedings 54 (2010): 1595-99. 